\title{
5 \\ Characteristics of the Tasmanian marriage cohorts
}

This chapter describes the characteristics of the group of interest in the analysis of the Tasmanian historical fertility decline- that is, the complete group, in which women were in their first marriage, had at least one child of that marriage and both partners survived the wife's childbearing years. The chapter examines these couples according to their characteristics at marriage: marital status, age at marriage, age difference between husband and wife, religion and whether the husband and/or wife signed the marriage register. The husband's socioeconomic status and the couple's geographic location - two important characteristics relating to theories of fertility decline-are also examined.

In the first section of this chapter, I describe the types of marriages in each of the four marriage cohorts, to look at the complete group in the context of the entire marriage cohort.

\section{Types of marriage}

The database consisted of 3,184 couples marrying in Tasmania in the years 1860, 1870, 1880 and 1890 (Table 5.1). The smallest marriage cohort was the 1870 cohort, with 673 couples, while the 1890 cohort was the largest, with 952 couples.

Most couples marrying in Tasmania in these years were couples in which the wife was in her first marriage and there were children of that marriage. There were four types of these couples: the 'complete' group, in which both parents survived the childbearing years (the study population); the 
'incomplete' group, in which one or both parents died during the wife's childbearing years; the 'unobserved' group, in which the couple could not be traced to the end of the wife's childbearing years; and couples with prenuptial births or two or more ex-nuptial births. The remainder were couples for whom the wife was in her first marriage and there were no children of the marriage and couples for whom the woman was a widow when marrying.

Table 5.1 Type of marriage: $1860,1870,1880$ and 1890 marriage cohorts, Tasmania

\begin{tabular}{|c|c|c|c|c|}
\hline Marriage cohort & 1860 & 1870 & 1880 & 1890 \\
\hline Type of marriage & \multicolumn{4}{|c|}{ Number } \\
\hline Widow at marriage & 104 & 102 & 93 & 81 \\
\hline Wife's first marriage, no children & 86 & 79 & 92 & 102 \\
\hline Wife's marital status unknown, no children & 41 & 17 & 5 & 4 \\
\hline \multicolumn{5}{|l|}{ Wife's first marriage with children } \\
\hline Complete & 256 & 283 & 417 & 529 \\
\hline Incomplete & 121 & 122 & 156 & 162 \\
\hline Unobserved & 75 & 40 & 59 & 50 \\
\hline Premarital births & 30 & 30 & 29 & 24 \\
\hline \multirow[t]{2}{*}{ Total } & 713 & 673 & 846 & 952 \\
\hline & \multicolumn{4}{|c|}{ Percentage } \\
\hline Widow at marriage & 14.6 & 15.2 & 11.0 & 8.5 \\
\hline Wife's first marriage, no children & 12.1 & 11.7 & 10.9 & 10.7 \\
\hline Wife's marital status unknown, no children & 5.8 & 2.5 & 0.6 & 0.4 \\
\hline Wife's first marriage with children & 67.6 & 70.6 & 78.1 & 80.4 \\
\hline Complete & 53.1 & 59.6 & 63.1 & 69.2 \\
\hline Incomplete & 25.1 & 25.7 & 23.6 & 21.2 \\
\hline Unobserved & 15.6 & 8.4 & 8.9 & 6.5 \\
\hline Premarital births & 6.2 & 6.3 & 4.4 & 3.1 \\
\hline Total & 100.0 & 100.0 & 100.0 & 100.0 \\
\hline
\end{tabular}

Women who were in their first marriage and had children of that marriage accounted for two-thirds of women marrying in 1860, but this rose to 80 per cent by 1890 (Table 5.1).

Of this group, the proportion for whom both partners survived the wife's childbearing years - the complete group-increased from just over half in 1860 to around two-thirds in 1890 . For almost all these couples, both 
husband and wife survived until the wife turned 50 years of age. However, as noted, there was a small proportion where both partners did not survive until the wife turned 50 but there was a very high probability the couple had completed their childbearing.

The proportion of couples where the husband and/or wife died before the wife turned 50 and who had not completed their childbearing- the incomplete group-fell slightly, from 25.1 per cent in 1860 to 21.2 per cent in 1890 . In the 1860 and 1880 cohorts, a higher proportion of husbands than wives died, whereas a higher proportion of wives than husbands died in the other two cohorts (Appendix A: Table A.16). A small number of couples in the incomplete group were separated or divorced.

The unobserved group - that is, couples whom I could not trace to the end of the wife's childbearing years-accounted for 15.6 per cent of couples with children in the 1860 cohort, but that fell to 6.5 per cent in the 1890 cohort (Table 5.1). The relatively high proportion of 'unknown' couples in the 1860 cohort reflects the difficultly of tracing these couples compared with couples in the other cohorts.

Most couples with premarital births had one or more births before marriage. Only a small proportion were couples where the wife had two or more ex-nuptial births with a man other than the husband. The proportion of couples with premarital births halved from 6.2 per cent in 1860 to 3.1 per cent in 1890 (Table 5.1). Some of these couples survived the wife's childbearing years; in others, one spouse died, while others had unobserved outcomes. As discussed previously, these couples are excluded from the fertility analysis.

Widows made up a much larger proportion of the women marrying in the early cohorts, accounting for around 15 per cent of women marrying in 1860 and 1870 , but only 8.5 per cent in 1890 (Table 5.1).

Women in their first marriage with no children of that marriage accounted for 11-12 per cent of every marriage cohort (Table 5.1).

In every marriage cohort, there was a small proportion of women without children whose marital status was unknown (Table 5.1). However, the proportion dropped from 5.8 per cent of women in the 1860 cohort to 0.4 per cent in the 1890 cohort, with the improvement in the recording of marital status over the period. Around half of these women were aged 25 years and older, suggesting they may have been widows. 


\section{Characteristics of the complete group}

Data on the detailed characteristics of the incomplete and unknown groups can be found in Moyle (2015: Appendix Tables A5.10-A5.26).

\section{Marital status of husband and wife}

It is difficult to comment on the marital status of men marrying in the two earlier marriage cohorts, because so many of the data are missing. However, in 1880 and 1890, almost all women married bachelors, with only a very small proportion marrying widowers (Table 5.2).

Table 5.2 Marital status of husband and wife, complete group: 1860, 1870, 1880 and 1890 marriage cohorts, Tasmania

\begin{tabular}{|l|r|r|r|r|r|}
\hline Marriage cohort & 1860 & 1870 & 1880 & 1890 \\
\hline Marital status of husband and wife at marriage & \multicolumn{4}{|c|}{ Percentage } \\
\hline Spinster, husband's marital status not given & 35.5 & 25.1 & 0.4 & 1.7 \\
\hline Spinster married bachelor & 57.0 & 69.6 & 92.8 & 94.1 \\
\hline Spinster married widower & 7.4 & 5.3 & 6.7 & 4.2 \\
\hline Total (\%) & 100.0 & 100.0 & 100.0 & 100.0 \\
\hline Total (no.) & 256 & 283 & 417 & 529 \\
\hline
\end{tabular}

\section{Wife's age at marriage}

Legally, men and women who were single at marriage could not marry if they were under 21 years of age unless they had obtained their parents' consent to the marriage. Most women were young at marriage, with the mean age of 21.5 years (median 21.5) for the 1860 cohort, increasing to 23.1 years (median 22.3) for the 1890 cohort (Table 5.3).

Just under half of the women in the first three marriage cohorts were aged under 21 years at marriage, but this fell sharply to 31.2 per cent for the 1890 cohort. The proportion of women marrying as teenagers also fell markedly between the 1860 and 1890 cohorts, from 38.3 per cent to 21.4 per cent, while the proportion marrying at ages 25-29 years almost doubled over the four marriage cohorts. These differences are not explained by differences in the age structure of the population (Table 3.3, Appendix A: Table A.5), but may be related to the increase in the ratio of unmarried women to unmarried men in the marriageable age group. 
Table 5.3 Wife's age at marriage, complete group: 1860, 1870, 1880 and 1890 marriage cohorts, Tasmania

\begin{tabular}{|l|r|r|r|r|}
\hline Marriage cohort & 1860 & 1870 & 1880 & 1890 \\
\hline Age at marriage & \multicolumn{4}{|c|}{ Percentage } \\
\hline$<20$ years & 38.3 & 35.3 & 30.5 & 21.4 \\
\hline$<21$ years & 49.6 & 46.6 & 45.8 & 31.2 \\
\hline $21-24$ years & 34.4 & 33.2 & 37.6 & 40.3 \\
\hline 25-29 years & 11.3 & 14.8 & 9.6 & 20.8 \\
\hline 30-34 years & 3.9 & 4.2 & 4.8 & 5.8 \\
\hline 35-39 years & 0.8 & 1.1 & 1.4 & 0.8 \\
\hline 40-44 years & 0.0 & 0.0 & 0.0 & 0.2 \\
\hline Missing & 0.0 & 0.0 & 0.7 & 0.9 \\
\hline Total (\%) & 100.0 & 100.0 & 100.0 & 100.0 \\
\hline Total (no.) & 256 & 283 & 417 & 529 \\
\hline Mean/median & \multicolumn{5}{|c|}{ Age at marriage } \\
\hline Mean & 21.5 & 22.0 & 22.0 & 23.1 \\
\hline Median & 21.0 & 21.3 & 21.2 & 22.3 \\
\hline
\end{tabular}

Note: Means and medians exclude missing data.

The high proportion of women in Tasmania marrying at a young age is consistent with trends in similar 19th-century frontier societies (Bean et al. 1992; Gauvreau 1992, cited in Vézina et al. 2014). The mean age at marriage for those marrying in the Saguenay region of Quebec, for example, was 21-22 years for those marrying in the second half of the 19th century (Vézina et al. 2014).

The somewhat later age of marriage for women in the 1890 Tasmanian cohort is similar to trends in other Australian colonies. Women marrying in Victoria in 1881 and 1891 and in South Australia in 1891 also married at somewhat older ages than in previous years (McDonald 1974). McDonald attributes this partly to the idea of a 'proper time to marry'that is, the need to maintain living standards for the middle classes and the rising aspirations of the working class.

\section{Husband's age at marriage}

On average, men were five or six years older than their wives, with the mean age at marriage for men 26-27 years (Table 5.4). Mean age at marriage fell from 27.6 years (median 26.7) for the 1860 cohort to 
26.2 years (median 24.5 years) for the 1870 cohort and then increased to 26.8 years (median 25.4) for the 1890 cohort. Unlike women, in every marriage cohort, only a small proportion of men married under the age of consent. The proportion of men marrying at age 35 and older was higher in 1860 than in the other three marriage cohorts, with 15.3 per cent of men aged 35 years or older in 1860 compared with 9-10 per cent in the other cohorts. This is consistent with changes in the age structure of the male population in Tasmania over this period, with the male population becoming younger between 1861 and 1891 (Table 3.4, Appendix A: Table A.6).

Table 5.4 Husband's age at marriage, complete group: 1860, 1870, 1880 and 1890 marriage cohorts, Tasmania

\begin{tabular}{|l|r|r|r|r|r|}
\hline Marriage cohort & 1860 & 1870 & 1880 & 1890 \\
\hline Age at marriage & \multicolumn{4}{|c|}{ Percentage } \\
\hline$<21$ years & 9.8 & 11.3 & 7.7 & 8.3 \\
\hline 21-24 years & 31.3 & 42.8 & 44.6 & 36.1 \\
\hline 25-29 years & 31.6 & 23.7 & 29.5 & 32.5 \\
\hline 30-34 years & 12.1 & 12.4 & 9.1 & 14.0 \\
\hline 35-39 years & 9.0 & 4.9 & 5.0 & 4.2 \\
\hline 40-44 years & 3.5 & 0.7 & 1.4 & 3.0 \\
\hline$>45$ years & 1.6 & 2.8 & 0.7 & 0.8 \\
\hline Missing & 1.2 & 1.4 & 1.9 & 1.1 \\
\hline Total (\%) & 100.0 & 100.0 & 100.0 & 100.0 \\
\hline Total (no.) & 256 & 283 & 417 & 529 \\
\hline Mean/median & \multicolumn{5}{|c|}{ Age at marriage } \\
\hline Mean & 27.6 & 26.2 & 26.0 & 26.8 \\
\hline Median & 26.7 & 24.5 & 24.8 & 25.4 \\
\hline
\end{tabular}

Note: Means and medians exclude missing data.

\section{Age difference between husband and wife}

Although husbands were older than their wives on average, a slightly different picture emerges when looking at the actual age difference between spouses (Table 5.5). The largest proportion of couples was those where the men were the same age as their wives or up to four years older, ranging from 36.7 per cent of the 1860 cohort to 46.1 per cent of the 1890 cohort. Men in the 1860 cohort were more likely to be much older 
than their wives: just over half of men in the 1860 cohort were five or more years older than their wives compared with around one-third in the other marriage cohorts. One-quarter of all men in the 1860 cohort were 10 or more years older than their spouse. In contrast, women in the 1860 marriage cohort were less likely to be older than their husbands: around 10 per cent of women in the 1860 marriage cohort were older than their husbands, compared with 17-18 per cent of wives in all other cohorts. These differences may be related to changes in the age structure of the male population over the period.

Table 5.5 Age difference between husband and wife at marriage, complete group: 1860, 1870, 1880 and 1890 marriage cohorts, Tasmania

\begin{tabular}{|l|r|r|r|r|}
\hline Marriage cohort & 1860 & 1870 & 1880 & 1890 \\
\hline Age difference & \multicolumn{3}{|c|}{ Percentage } \\
\hline Wife 5 or more years older & 1.2 & 1.1 & 3.2 & 2.3 \\
\hline Wife 1-4 years older & 8.6 & 16.6 & 13.7 & 16.1 \\
\hline Same age or husband 1-4 years older & 36.7 & 43.5 & 44.8 & 46.1 \\
\hline Husband 5-9 years older & 27.3 & 20.1 & 24.5 & 20.8 \\
\hline Husband 10-14 years older & 16.8 & 11.0 & 8.4 & 9.2 \\
\hline Husband 15 or more years older & 8.2 & 6.4 & 3.8 & 3.6 \\
\hline Husband's and/or wife's age unknown & 1.2 & 1.4 & 1.9 & 1.9 \\
\hline Total (\%) & 100.0 & 100.0 & 100.0 & 100.0 \\
\hline Total (no.) & 256 & 283 & 417 & 529 \\
\hline
\end{tabular}

\section{Religion}

Almost all couples were married by a minister of religion, in either a church or a minister's house, although some couples were married by a minister in a private residence. Only four couples were married in a civil ceremony in a registry office-one in 1880 and three in 1890 .

Couples were married according to several different types of religious rites (Table 5.6). Couples who married according to the rites of the Church of England or the United Church of England and Ireland are classified as Anglican and those married according to the rites of the Holy Catholic Church are classified as Catholics. Presbyterians are couples marrying according to the rites of the (Free) Presbyterian Church and the (Free) Church of Scotland. Methodists are couples who married according to the rites of the Wesleyan Methodist Church, the Primitive 
Methodist Church and the United Free Methodist Church. Other Nonconformists are couples who married according to the rites of the Baptist Church, Congregationalist/Independent Church, the Christian Mission Church and those marrying in a civil ceremony. The composition of Other Nonconformists changed over the marriage cohorts, with Congregationalists/Independents accounting for almost all the group in the 1860 and 1870 cohorts, but Baptists making up half the group in the 1890 cohort (Moyle 2015: Table A5.16). A very small number of couples in all cohorts married in two ceremonies-as Catholics and according to the rites of another religion. I have classified these couples as Catholics for the purposes of the fertility analysis.

Anglicans made up just under half of couples marrying in 1860, but this fell over the four marriage cohorts to just under one-third in 1890 (Table 5.6). Catholics made up 9-12 per cent of couples in every marriage cohort and Presbyterians 13-17 per cent. Methodists and Other Nonconformists accounted for an increasing proportion of couples marrying in each cohort. Between 1860 and 1890, the proportion of Methodists increased from 13.3 per cent to 22.3 per cent, while that of Other Nonconformists increased from 11.3 per cent to 20 per cent.

Table 5.6 Type of religion at marriage, complete group: 1860, 1870, 1880 and 1890 marriage cohorts, Tasmania

\begin{tabular}{|l|r|r|r|r|}
\hline Marriage cohort & 1860 & 1870 & 1880 & 1890 \\
\hline Type of religion at marriage & \multicolumn{3}{|c|}{ Percentage } \\
\hline Anglican & 45.7 & 37.1 & 33.3 & 31.8 \\
\hline Catholic & 12.5 & 8.8 & 12.5 & 10.0 \\
\hline Presbyterian & 16.8 & 13.8 & 12.9 & 15.8 \\
\hline Methodist & 13.3 & 19.1 & 23.3 & 22.3 \\
\hline Other Nonconformist & 11.3 & 21.2 & 18.0 & 20.0 \\
\hline Missing & 0.4 & 0.0 & 0.0 & 0.0 \\
\hline Total (\%) & 100.0 & 100.0 & 100.0 & 100.0 \\
\hline Total (no.) & 256 & 283 & 417 & 529 \\
\hline
\end{tabular}

It is difficult to compare the distribution of religion at marriage for the complete group with population data, since the census data are not disaggregated by age or sex and include persons under 15 years of age and over 45 years - that is, people who were not in the 'marrying ages' (Table 3.6). In both 1861 and 1870, Catholics accounted for around 
22 per cent of the population of Tasmania, but the Catholic population consisted of a large proportion of Irish ex-convicts who would have been over 45 years of age (Alexander 2014).

\section{Signing the marriage register}

Both husband and wife signed the marriage register in most marriages, with the proportion increasing from 76.2 per cent in the 1860 cohort to 94.9 per cent in the 1890 cohort (Table 5.7). This increase reflects the introduction of compulsory education in 1868 and the subsequent increase in literacy over the period (Table 3.8). In only a very small proportion of couples, neither the husband nor the wife signed the marriage register, with the proportion falling from 6.6 per cent to 0.8 per cent between the 1860 and 1890 cohorts. These trends are very similar to population trends, with the proportion of the population (of any age) able to read and write increasing from 53.7 per cent to 70.3 per cent between 1861 and 1891 (Table 3.8). The proportion of couples in the 1890 cohort of whom both husband and wife signed the register (94.9 per cent) was very similar to the proportion of the Tasmanian population aged 20-29 years who could read and write (93.3 per cent) (TAS 1891: 04_90).

Table 5.7 Whether husband and/or wife signed the marriage register, complete group: 1860, 1870, 1880 and 1890 marriage cohorts, Tasmania

\begin{tabular}{|l|r|r|r|r|}
\hline Marriage cohort & 1860 & 1870 & 1880 & 1890 \\
\hline Signing the marriage register & \multicolumn{4}{|c|}{ Percentage } \\
\hline Both husband and wife signed & 76.2 & 80.6 & 86.8 & 94.9 \\
\hline Wife did not sign, husband signed & 9.8 & 7.8 & 4.8 & 1.3 \\
\hline Husband did not sign, wife signed & 7.4 & 6.4 & 7.0 & 3.0 \\
\hline Neither husband nor wife signed & 6.6 & 5.3 & 1.4 & 0.8 \\
\hline Total (\%) & 100.0 & 100.0 & 100.0 & 100.0 \\
\hline Total (no.) & 256 & 283 & 417 & 529 \\
\hline
\end{tabular}

\section{Occupation and socioeconomic status}

As outlined in Chapter 4, the husband's occupation was obtained from the birth registration data or imputed from other sources. Data on married women's occupations were not available. In 19th-century Tasmania, married women were unlikely to work outside the home, although many women helped in the family business or on the farm and some women took in washing or sewing at home. 
As noted in Chapter 4, for the bivariate analysis, I examined the husband's occupation and socioeconomic status according to his occupation at the birth of the first child, and for the multivariate analysis, I used the husband's occupation at the birth of each specific child. This is important since occupation and socioeconomic status could change over the course of the wife's childbearing years. The more births the couple had, the more information is available about changes in the husband's occupation. However, if a couple had a small number of births in a relatively short period, the opportunity to observe occupational change is very limited.

It is also important to note that the composition of various occupational groups may have changed between the marriage cohorts. For example, given the changes in farming that occurred in Tasmania in the second half of the 19th century with the growth of selectors, the waning importance of sheep farming and increasing importance of fruit growing, farmers in the 1860 cohort may have been quite a different group from those in the 1890 cohort.

The occupational data in the Tasmanian Civil Registration Database were classified to the detailed five-digit classification system of the Historical International Classification of Occupations (HISCO) and then to the nine broad HISCO occupational groups (HISCO 2013). Each HISCO code was then classified to one of the 12 occupational Historical International Social Class Scheme (HISCLASS) categories to obtain a measure of socioeconomic status (Van Leeuwen and Maas 2005).

In all four marriage cohorts, the largest proportion of men was engaged in mining, manufacturing and transport (Table 5.8). More than one-third of men in the 1860 and 1870 cohorts were engaged in agriculture, forestry, fishery and hunting, but this dropped to one-quarter in the 1880 and 1890 cohorts, with a corresponding rise in the proportions engaged in mining, manufacturing and transport. The proportion of men who were professional, administrative, clerical, sales or service workers was lowest in 1870 , at 16.3 per cent, but had risen to 21 per cent by 1890 .

These trends mirror changes in economic conditions in Tasmania over the period and are consistent with trends in the broad occupational data for the Tasmanian population (Appendix A: Tables A.8-10). Examination of the detailed occupational data in the four marriage cohorts (Moyle 2012) shows an increase in the diversity of occupations that occurred in late 19th-century Australia (McDonald 1974). New occupations-such 
as mining manager, railway porter, coffee house proprietor and pastry cook-appeared from 1880. Specialist shopkeepers, such as florists, tobacconists and wine merchants, also became more common, reflecting improving living standards.

Table 5.8 Husband's occupational group (HISCO) at the birth of the first child, complete group: 1860, 1870, 1880 and 1890 marriage cohorts, Tasmania

\begin{tabular}{|l|r|r|r|r|}
\hline Marriage cohort & 1860 & 1870 & 1880 & 1890 \\
\hline HISCO occupational group & \multicolumn{3}{|c|}{ Percentage } \\
\hline Professional, technical and related workers & 5.1 & 4.2 & 5.0 & 5.3 \\
\hline Administrative and managerial workers & 1.2 & 2.5 & 2.6 & 4.5 \\
\hline Clerical and related workers & 5.1 & 2.8 & 3.6 & 4.7 \\
\hline Sales workers & 3.9 & 3.9 & 3.4 & 4.7 \\
\hline Service workers & 2.0 & 2.8 & 3.4 & 1.7 \\
\hline Agriculture, forestry, fishery, hunting & 35.2 & 41.0 & 27.8 & 26.3 \\
\hline Mining, manufacturing and transport & 46.5 & 42.0 & 53.7 & 52.0 \\
\hline Missing & 1.2 & 0.7 & 0.5 & 0.8 \\
\hline Total (\%) & 100.0 & 100.0 & 100.0 & 100.0 \\
\hline Total (no.) & 256 & 283 & 417 & 529 \\
\hline
\end{tabular}

In relation to socioeconomic status, based on HISCLASS, farmers accounted for around one-quarter of all men, except in the 1870 cohort, in which they accounted for more than one-third (Table 5.9). The proportion of men who were unskilled workers was 32.4 per cent in the 1860 cohort but fell to 25.6 per cent in the 1890 cohort, mainly because of the fall in the proportion of unskilled farm workers. The proportions of lower-skilled and of managerial, professional, clerical and sales workers increased between the 1860 and 1890 cohorts, from 7 per cent to 14 per cent for lower-skilled workers and from 16 per cent to 21 per cent for managerial, professional, clerical and sales workers. Skilled workers made up around 16 per cent of workers in all marriage cohorts. These data are not comparable with population census data because the census did not classify occupation by socioeconomic status; however, they appear to be consistent with the census data. 
Table 5.9 Husband's socioeconomic status (HISCLASS) at the birth of the first child, complete group: 1860, 1870, 1880 and 1890 marriage cohorts, Tasmania

\begin{tabular}{|l|r|r|r|r|r|}
\hline Marriage cohort & 1860 & 1870 & 1880 & 1890 \\
\hline HISCLASS group & \multicolumn{4}{|c|}{ Percentage } \\
\hline Higher managers (1) & 0.0 & 1.1 & 1.4 & 1.3 \\
\hline Higher professionals (2) & 3.1 & 2.8 & 4.6 & 4.5 \\
\hline Lower managers (3) & 1.6 & 2.5 & 1.9 & 4.7 \\
\hline Lower professional and clerical, sales (4) & 7.4 & 6.0 & 5.3 & 6.6 \\
\hline Lower clerical and sales (5) & 3.9 & 3.2 & 4.8 & 3.8 \\
\hline Foremen (6) & 0.4 & 0.0 & 0.0 & 0.0 \\
\hline Skilled workers (7) & 16.4 & 14.5 & 17.3 & 16.1 \\
\hline Farmers (8) & 27.0 & 36.4 & 24.0 & 23.3 \\
\hline Lower-skilled workers (9) & 6.6 & 6.0 & 11.5 & 14.0 \\
\hline Lower-skilled farm workers (10) & 0.4 & 1.1 & 1.2 & 0.0 \\
\hline Unskilled workers (11) & 24.2 & 22.3 & 25.4 & 22.6 \\
\hline Unskilled farm workers (12) & 8.2 & 3.5 & 2.6 & 3.0 \\
\hline Missing & 0.8 & 0.7 & 0.0 & 0.0 \\
\hline Total (\%) & 100.0 & 100.0 & 100.0 & 100.0 \\
\hline Total (no.) & 256 & 283 & 417 & 529 \\
\hline
\end{tabular}

Note: Numbers in parentheses are the HISCLASS category numbers.

In Table 5.9, all men who gave their occupation as farmer are classified in the HISCLASS category 'Farmer (8)'. However, the occupation 'farmer' is difficult to classify, since the term can cover a wide range of circumstances (Van Leeuwen and Maas 2005). In 19th-century Tasmania, there was a group of gentlemen farmers, many of whom owned large properties in the Midlands (Reynolds 1969, 2012; Meikle 2011). They called themselves farmers but employed others to manage their landholdings. I reclassified farmers to the HISCLASS category 'Higher manager (1)' if the husband or wife was a member of these large landowning families identified in Boyce (2010) and Reynolds (1969, 2012). I also reclassified other men to this category who identified themselves as 'gentleman farmer' on their children's birth registrations if I could find information supporting their claim-for instance, their marriage was reported in a newspaper and they were named as an 'Esquire' or the 'son of an Esquire'. The number of farmers reclassified as 'Higher manager (1)' was 12 in 1860, 10 in 1870, 11 in 1880 and seven in 1890 . 
Because of small numbers in some HISCLASS groups, in the analyses that follow, the husband's socioeconomic status has been reclassified into five groups: white-collar (HISCLASS 1, 2, 3, 4 and 5); skilled workers (6 and 7); farmers (8); lower-skilled workers (9 and 10); and unskilled workers (11 and 12). With the reclassification of gentlemen farmers as higher managers, white-collar workers accounted for around 20 per cent of men in all marriage cohorts, while farmers made up around 22 per cent of every cohort except the 1870 cohort, of which they accounted for onethird (Table 5.10). The 1870 group of farmers probably included a large group of 'selectors', some of whom were unsuccessful at farming in the longer term.

Table 5.10 Husband's socioeconomic status at the birth of the first child, complete group: 1860, 1870, 1880 and 1890 marriage cohorts, Tasmania

\begin{tabular}{|l|r|r|r|r|}
\hline Marriage cohort & 1860 & 1870 & 1880 & 1890 \\
\hline Occupational status & \multicolumn{3}{|c|}{ Percentage } \\
\hline White-collar & 20.7 & 19.1 & 20.6 & 22.5 \\
\hline Skilled workers & 16.8 & 14.5 & 17.3 & 16.1 \\
\hline Farmers & 22.3 & 32.9 & 21.3 & 21.7 \\
\hline Lower-skilled & 7.0 & 7.1 & 12.7 & 14.0 \\
\hline Unskilled & 32.4 & 25.8 & 28.1 & 25.7 \\
\hline Missing & 0.8 & 0.7 & 0.0 & 0.0 \\
\hline Total (\%) & 100.0 & 100.0 & 100.0 & 100.0 \\
\hline Total (no.) & 256 & 283 & 417 & 529 \\
\hline
\end{tabular}

As noted above, men did not necessarily stay in the same occupation for the duration of their wife's childbearing years. Around 40 per cent of men in the three earlier marriage cohorts who had more than one child changed their socioeconomic status some time between the birth of the first child and the birth of the last child (Table 5.11). Many also changed their occupation but stayed within the same socioeconomic status group. The patterns of change by socioeconomic status were varied: some men had the same socioeconomic status for most of the wife's childbearing years and then changed their occupation and status towards the end of this period; others had one occupation for the first few years, but changed their occupation and status for the remainder of the period; others changed their occupation and status at some time and then changed back to their previous occupation (and status) for the rest of the period; while others changed their occupation (and status) periodically. 
Table 5.11 Occupational characteristics of husbands between first and last births for couples with more than one child, complete group: $1860,1870,1880$ and 1890 marriage cohorts, Tasmania

\begin{tabular}{|l|r|r|r|r|}
\hline Marriage cohort & 1860 & 1870 & 1880 & 1890 \\
\hline Occupational characteristic & \multicolumn{4}{|c|}{ Percentage of total } \\
\hline Changed occupational status & 42.0 & 43.7 & 42.9 & 30.2 \\
\hline Was a farmer for some or all of the period & 42.8 & 49.3 & 36.0 & 33.1 \\
\hline
\end{tabular}

Note: Includes only couples with two or more children.

One reason for these changes may be that a large proportion of men were farmers at some time during this period (Table 5.11). Some of these men may have taken up a different occupation because they were unsuccessful at farming, while others may have been selectors, who often worked as labourers, miners or sawyers while they were establishing their farms in the rugged and inaccessible country in the north of Tasmania (Reynolds 2012). The discovery of precious minerals in various parts of Tasmania in the final three decades of the 19th century also encouraged men to leave their jobs and work as miners. The proportion of men who changed their occupational status and/or were ever a farmer was somewhat lower in the 1890 cohort. This is probably because the occupational data for 20thcentury births were of much poorer quality and because people tended to have smaller families so opportunities to observe occupational change were more limited.

\section{Geographic location}

In examining the geographic area where the family lived, I used the location of the children's births rather than the location of the marriage. Couples were often married in a location different from that of the births of their first and subsequent children. For instance, a couple may have married in the bride's parents' house, but then gone to live in another location.

In 19th and early 20th-century Tasmania, most children were born in the parents' home, although a small number were born in private hospitals (lying-in homes). Births did not take place in public hospitals until well into the 20th century. Only nine of the 2,974 births to the 1890 cohort were in a public hospital. There is a small number of cases where it appears 
a woman may have come from the country to give birth in a hospital in Hobart or Launceston, but in almost all cases the location of the place of birth was the same as the location of the family's residence.

When I began to develop a classification of geographic location of the family's residence, I wanted to use a measure that discriminated between rural and more remote geographic areas and differentiated the population living in large towns such as Devonport and Beaconsfield from the population living in smaller hamlets. However, prior to 1896, although parents were required to register the 'place of birth', only the registration district was recorded on most birth registrations. Rural registration districts covered both regional towns and more remote areas. Boundaries often changed and the number of registration districts increased markedly between 1859 and 1913, from 30 to 55 (TAHO 2014). From 1896, the name of the place where a child was born was included on all birth registrations, probably because the 1895 Registration Act brought in a fine of $£ 10$ for parents who 'did not give to the Registrar ... information of the particulars required to be registered' (TAS 1895). Even where a placename was given, this often covered a large area-for instance, a mining town and the agricultural areas surrounding that town. This made it impossible to develop a consistent, detailed geographic classification for the four marriage cohorts or even to develop a detailed classification for the last cohort.

For this reason, I assigned the Tasmanian births to an urban or rural category, with urban comprising the Hobart and Launceston registration districts and rural all other Tasmanian registration districts. Even this was not perfect, since both the Hobart and the Launceston registration districts contained some outlying rural areas, such as Glenorchy in the Hobart registration district. Births that occurred outside Tasmania were assigned to the category Outside Tasmania, as I did not always have the information to classify the location to an urban or rural category and numbers were relatively small.

While the bivariate analysis is based on the type of geographic location at the birth of the couple's first child, as noted, many couples were very mobile and had children born in different geographic locations. A couple could move from an urban area to a rural area, for instance, or from an urban area in Tasmania to another colony. Many couples also moved within rural areas-for instance, from the Tasmanian Midlands 
to the north-west of the island. It is very difficult to develop data on moves within rural areas of Tasmania because of the constant addition of new registration districts and changes in registration district boundaries. As with data on husband's occupation, the more births the couple had, the more information I have about their geographical mobility. As with socioeconomic status, the actual geographic location at the time of each child's birth is used in the multivariate analysis.

Consistent with the spread of the population in Tasmania, higher proportions of first births to all cohorts were in areas outside Hobart and Launceston (rural) than in the two cities (urban) (Table 5.12). In the last three marriage cohorts, around 60 per cent of first births were in Tasmanian rural districts, while 32-37 per cent were in urban areas. Only a small proportion of first births in all cohorts (4-8 per cent) were outside Tasmania.

Table 5.12 Type of location of first birth, complete group: 1860, 1870, 1880 and 1890 marriage cohorts, Tasmania

\begin{tabular}{|l|r|r|r|r|r|}
\hline Marriage cohort & 1860 & 1870 & 1880 & 1890 \\
\hline Type of location & \multicolumn{4}{|c|}{ Percentage } \\
\hline Urban & 42.2 & 32.2 & 37.2 & 35.9 \\
\hline Rural & 51.2 & 60.1 & 58.5 & 59.0 \\
\hline Outside Tasmania & 6.6 & 7.8 & 4.3 & 5.1 \\
\hline Total (\%) & 100.0 & 100.0 & 100.0 & 100.0 \\
\hline Total (no.) & 256 & 283 & 417 & 529 \\
\hline
\end{tabular}

In looking at geographic mobility, as measured by the location of couples' births, I developed a classification that categorised couples according to whether all their children were born in Tasmania, whether they had some births in Tasmania and one or more elsewhere or whether all their children were born elsewhere. The proportion of couples who had all births in Tasmania increased over the marriage cohorts, from 78.9 per cent to 88.7 per cent (Table 5.12). This was because of a decrease in the proportion of couples having some births in Tasmania and some elsewhere, from 15.2 per cent in the 1860 cohort to 7.4 per cent in the 1890 cohort. The proportion of couples who had all births outside Tasmania was very small in all cohorts, from 3-6 per cent. 
Table 5.13 Location of all births, complete group: 1860, 1870, 1880 and 1890 marriage cohorts, Tasmania

\begin{tabular}{|l|r|r|r|r|}
\hline Marriage cohort & 1860 & 1870 & 1880 & 1890 \\
\hline Location of family births & \multicolumn{4}{|c|}{ Percentage } \\
\hline All births in Tasmania & 78.9 & 82.7 & 87.1 & 88.7 \\
\hline Births in and outside Tasmania & 15.2 & 11.7 & 10.1 & 7.4 \\
\hline All births outside Tasmania & 5.9 & 5.7 & 2.9 & 4.0 \\
\hline Total (\%) & 100.0 & 100.0 & 100.0 & 100.0 \\
\hline Total (no.) & 256 & 283 & 417 & 529 \\
\hline
\end{tabular}

Even using such a broad geographic measure, there is evidence that a substantial proportion of couples were mobile, particularly in the earliest cohort. In the 1860 cohort, one-third of all couples with two or more children changed their geographic location between their first and last births-for instance, they moved from an urban location to a rural location or from Tasmania to another colony (Table 5.14)

Table 5.14 Changes in type of geographic location (urban, rural, outside Tasmania) during the period between the first and last births for couples with more than one child, complete group: 1860, 1870, 1880 and 1890 marriage cohorts, Tasmania

\begin{tabular}{|l|r|r|r|r|}
\hline Marriage cohort & 1860 & 1870 & 1880 & 1890 \\
\hline Geographic mobility & \multicolumn{4}{|c|}{ Percentage } \\
\hline Remained in same type of location & 66.7 & 70.4 & 71.8 & 75.0 \\
\hline Changed type of geographic location & 33.3 & 29.6 & 21.2 & 25.0 \\
\hline Total (\%) & 100.0 & 100.0 & 100.0 & 100.0 \\
\hline Total (no.) & 243 & 270 & 408 & 504 \\
\hline
\end{tabular}

Note: Includes only couples with two or more children.

\section{Summary}

This chapter has examined the characteristics of couples in the four marriage cohorts for whom women were in their first marriage with at least one child of that marriage and both husband and wife survived the wife's childbearing years. An examination of the characteristics of the incomplete and unobserved groups (Moyle 2015: 75-89, 212-18) found the three groups are very similar. This indicates that the complete group is representative of marriages in which the wife was in her first marriage and there were children of that marriage, thus making it appropriate to use this group to analyse the decline in marital fertility over the period. 
This text is taken from Australia's Fertility Transition: A study of 19th-century Tasmania, by Helen Moyle, published 2020 by ANU Press, The Australian National University, Canberra, Australia.

doi.org/10.22459/AFT.2020.05 